\title{
Biogas technology for sustainable energy generation: development and perspectives
}

\begin{abstract}
Biogas from biomass appears to have potential as an alternative energy source, which is potentially rich in biomass resources. This is an overview of some salient points and perspectives of biogas technology. The current literature is reviewed regarding the ecological, social, cultural and economic impacts of biogas technology. This article gives an overview of present and future use of biomass as an industrial feedstock for production of fuels, chemicals and other materials. However, to be truly competitive in an open market situation, higher value products are required. Results suggest that biogas technology must be encouraged, promoted, invested, implemented, and demonstrated, but especially in remote rural areas.
\end{abstract}

Keywords: biomass resources, biogas application, sustainable development, environment
Volume I Issue 4 - 2017

\author{
Abdeen Omer \\ Energy Research Institute (ERI), United Kingdom
}

Correspondence: Abdeen Omer, Energy Research Institute (ERI), Nottingham, NG7 4EU, United Kingdom, Email abdeenomer2@yahoo.co.uk

Received: June 20, 2017 | Published: November 20, 2017

\section{Introduction}

Energy is an essential factor in development since it stimulates, and supports economic growth, and development. Fossil fuels, especially oil and natural gas, are finite in extent, and should be regards as depleting assets, and efforts are oriented to search for new sources of energy. The clamour all over the world for the need to conserve energy and the environment has intensified as traditional energy resources continue to dwindle whilst the environment becomes increasingly degraded. The basic form of biomass comes mainly from firewood, charcoal and crop residues. Out of the total fuel wood and charcoal supplies $92 \%$ was consumed in the household sector with most of firewood consumption in rural areas. The term biomass is generally applied to plant materials grown for non-food use, including that grown as a source of fuel. However, the economics of production are such that purpose-grown crops are not competitive with fossil-fuel alternatives under many circumstances in industrial countries, unless subsidies and/or tax concessions are applied. For this reason, much of the plant materials used as a source of energy at present are in the form of crop and forest residues, animal manure, and the organic fraction of municipal solid waste and agro-industrial processing by-products, such as bagasse, oil-palm residues, sawdust and wood off-cuts. The economics of use of such materials are improved since they are collected in one place and often have associated disposal costs. Combustion remains the method of choice for heat and power generation (using steam turbines) for dryer raw materials, while biogas production through anaerobic digestion or in landfills, is widely used for valorisation of wet residues and liquid effluents for heat and power generation (using gas engines or gas turbines). In addition, some liquid fuel is produced from purpose grown crops (ethanol from sugarcane, sugar beet, maize, sorghum and wheat or vegetable oil esters from rapeseed, sunflower, and palm trees). The use of wastes and residues has established these basic conversion technologies, although research, development and demonstration continues to try and improve the efficiency of thermal processing through gasification and pyrolysis, linked to combined cycle generation. At the same time considerable effort is being made to increase the range of plant-derived non-food materials. To achieve this several approaches are being taken. The first is to provide lower cost raw materials for production of bulk chemicals and ingredients that can be used in detergents, plastics, inks, paints and other surface coatings. To a large extent these are based on vegetable oils or starch hydrolysates used in fermentation to produced lactic acid (for polylactides) or polyhydroxbutyrate, as well as modified starches, cellulose and hemicellulose. The advantages are biodegradability, compatibility with biological systems (hence, less allergic reaction in use) and sparing of fossil carbon dioxide emissions (linked to climate change). Associating an economic value to these environmental benefits, linked to consumer preferences has contributed to increased production in this area.

The second expanding activity is the use of plant fibres, not only for non-tree paper, but also as a substitute for petroleum based plastic packing and components such as car parts. These may be derived from non-woven fibres, or be based on bio-composite materials (lingocellulose chips in a suitable plastic matrix). At the other end of the scale, new methods of gluing, strengthening, preserving and shaping wood have increased the building of large structures with predicted long-lifetimes. These include a wide range of natural products such as flavours, fragrances, hydrocolloids and biological control agents. In spite of decades of research and development, engineering (recombinant DNA technology) is being widely investigated to achieve this, as well as to introduce new routes to unusual fatty acids and other organic compounds. In addition such techniques are being used to construct plants that produce novel proteins and metabolites that may be used as vaccines or for other therapeutic use. Processing of the crops for all these non-food uses will again generate residues and by-products that can serve as a source of energy, for internal use in processing, or export to other users, suggesting the future possibility of large multi-product biomass-based industrial complexes.

\section{Technical description}

Bacteria form biogas during anaerobic fermentation of organic matters. The degradation is very complex process and requires certain environmental conditions as well as different bacteria populations. The complete anaerobic fermentation process is briefly described below as shown in Table 1, and Figure 1. Biogas is a relatively high- 
value fuel that is formed during anaerobic degradation of organic matter. The process has been known, and put to work in a number of different applications during the past 30years, for rural needs such as in Robinson $\mathrm{G}^{1}$. Food security, water supply, health cares, education and communications. During the last decades thousands of biogas units were built all over the world, producing methane $\mathrm{CH}_{4}$ for cooking, water pumping and electricity generation. In order not to repeat successes in depth on local conditions and conscientious planning urged. ${ }^{2}$ The goals should be achieved through:

A. Review and exchange of information on computer models and manuals useful for economic evaluation of biogas from biomass energy.

B. Exchange of information on methodologies for economic analysis and results from case studies.

C. Investigation of the constraints on the implementation of the commercial supply of biogas energy.

D. Investigation of the relations between supplies and demand for the feedstock from different industries.

E. Documentation of the methods and principles for evaluation of indirect consequences such as effects on growth, silvicultural treatment, and employment.

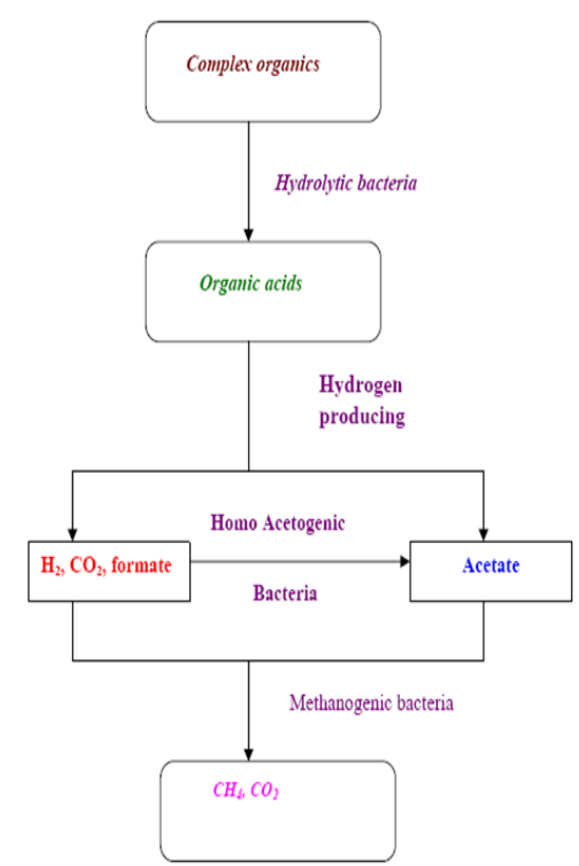

Figure I Biogas production process. ${ }^{3}$

Table I Anaerobic degradation of organic matter. ${ }^{3}$

\begin{tabular}{|c|c|c|c|}
\hline Level & Substance & Molecule & Bacteria \\
\hline Initial & Manure, vegetable, wastes & Cellulose, proteins & Cellulolytic, proteolytic \\
\hline Intermediate & $\begin{array}{l}\text { Acids, gases, oxidized, inorganic } \\
\text { salts }\end{array}$ & $\mathrm{CH}_{3} \mathrm{COOH}, \mathrm{CHOOH}, \mathrm{SO}_{4}, \mathrm{CO}_{2}, \mathrm{H}_{2}, \mathrm{NO}_{3}$ & Acidogenic, hydrogenic, sulfate reducing \\
\hline Final & $\begin{array}{l}\text { Biogas, reduced inorganic } \\
\text { compounds }\end{array}$ & $\mathrm{CH}_{4}, \mathrm{CO}_{2}, \mathrm{H}_{2} \mathrm{~S}, \mathrm{NH}_{3}, \mathrm{NH}_{4}$ & Methane formers \\
\hline
\end{tabular}

Biogas technology cannot only provide fuel, but is also important for comprehensive utilisation of biomass forestry, animal husbandry, fishery, agricultural economy, protecting the environment, realising agricultural recycling, as well as improving the sanitary conditions, in rural areas. The introduction of biogas technology on wide scale has implications for macro planning such as the allocation of government investment and effects on the balance of payments. Factors that determine the rate of acceptance of biogas plants, such as credit facilities and technical backup services, are likely to have to be planned as part of general macro-policy, as do the allocation of research and development funds. ${ }^{3,4}$ Biogas is a generic term for gases generated from the decomposition of organic material. As the material breaks down, methane $\left(\mathrm{CH}_{4}\right)$ is produced as shown in Figure 2. Sources that generate biogas are numerous and varied. These include landfill sites, wastewater treatment plants and anaerobic digesters. Landfills and wastewater treatment plants emit biogas from decaying waste. To date, the waste industry has focused on controlling these emissions to our environment and in some cases, tapping this potential source of fuel to power gas turbines, thus generating electricity. The primary components of landfill gas are methane $\left(\mathrm{CH}_{4}\right)$, carbon dioxide
$\left(\mathrm{CO}_{2}\right)$, and nitrogen $\left(\mathrm{N}_{2}\right)$. The average concentration of methane is $\sim 45 \%, \mathrm{CO}_{2}$ is $\sim 36 \%$ and nitrogen is $\sim 18 \%$. Other components in the gas are oxygen $\left(\mathrm{O}_{2}\right)$, water vapour and trace amounts of a wide range of non-methane organic compounds (NMOCs). ${ }^{4}$ For hot water and heating, renewables contributions come from biomass power and heat, geothermal direct heat, ground source heat pumps, and rooftop solar hot water and space heating systems. Solar assisted cooling makes a very small but growing contribution. When it comes to the installation of large amounts of PV, the cities have several important factors in common.

These factors include:

a. A strong local political commitment to the environment and sustainability.

b. The presence of municipal departments or offices dedicated to the environment, sustainability or renewable energy.

c. Information provision about the possibilities of renewables.

d. Obligations that some or all buildings include renewable energy. 


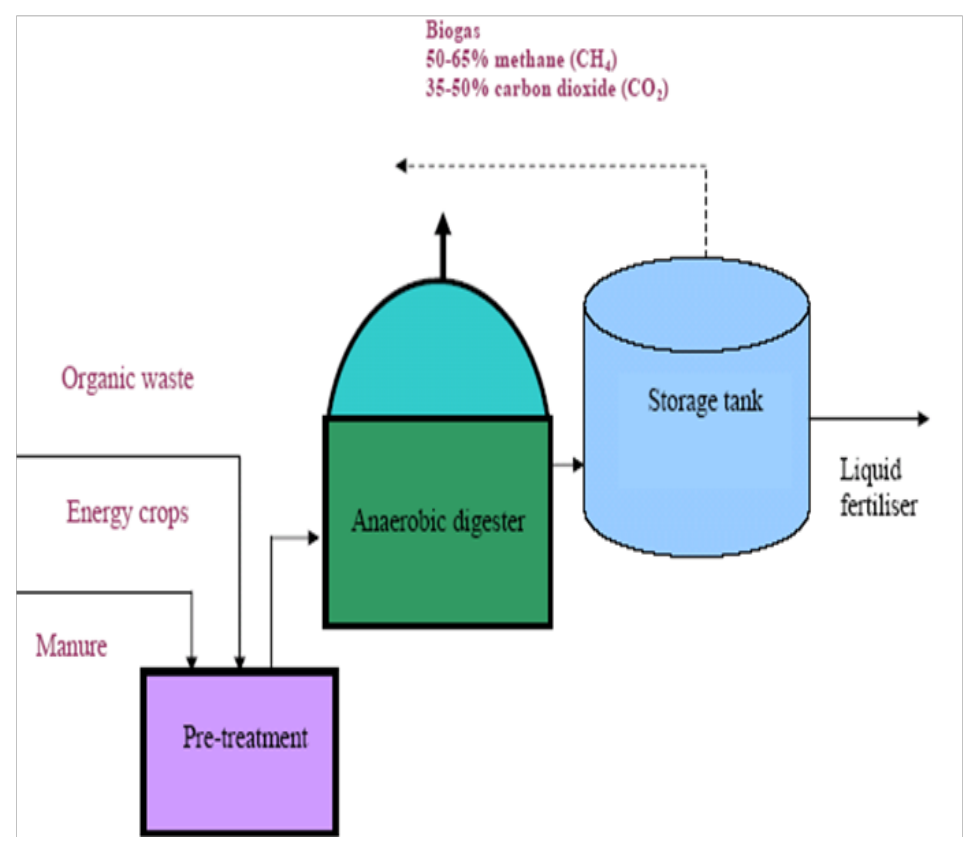

Figure 2 General schematic of an agricultural biogas plant. ${ }^{3}$

\section{Biogas utilisation}

The importance and role of biogases in energy production is growing. Nowadays, a lot of countries in Europe promote utilisation of renewable energies by guaranteed refund prices or emission trading systems. A general schematic of an agricultural biogas plant, with the anaerobic digester at the 'heart' of it as shown in Figure 2. Pretreatment steps (e.g., chopping, grinding, mixing or hygienisation) depend on the origination of the raw materials. In the past two decades the world has become increasingly aware of the depletion of fossil fuel reserves and the indications of climatic changes based on carbon dioxide emissions. Therefore extending the use of renewable resources, efficient energy production and the reduction of energy consumption are the main goals to reach a sustainable energy supply. Renewable energy sources include water and wind power, solar and geothermal energy, as well as energy from biomass. The technical achievability and the actual usage of these energy sources are different around Europe, but biomass is seen to have a great potential in many of them. An efficient method for the conversion of biomass to energy is the production of biogas by microbial degradation of organic matter under the absence of oxygen (anaerobic digestion). It is now possible to produce biogas at rural installation, upgrade it to bio-methane, feed it into the gas grid, use it in a heat demand-controlled CHP and to receive revenues. Biogas is a mixture containing predominantly methane $(50-65 \%$ by volume) and carbon dioxide and in a natural setting it is formed in swamps and anaerobic sediments, etc., due to its high methane concentration, biogas is a valuable fuel. Wet (40-95\%) organic materials with low lignin and cellulose content are generally suitable for anaerobic digestion (Figure 3).

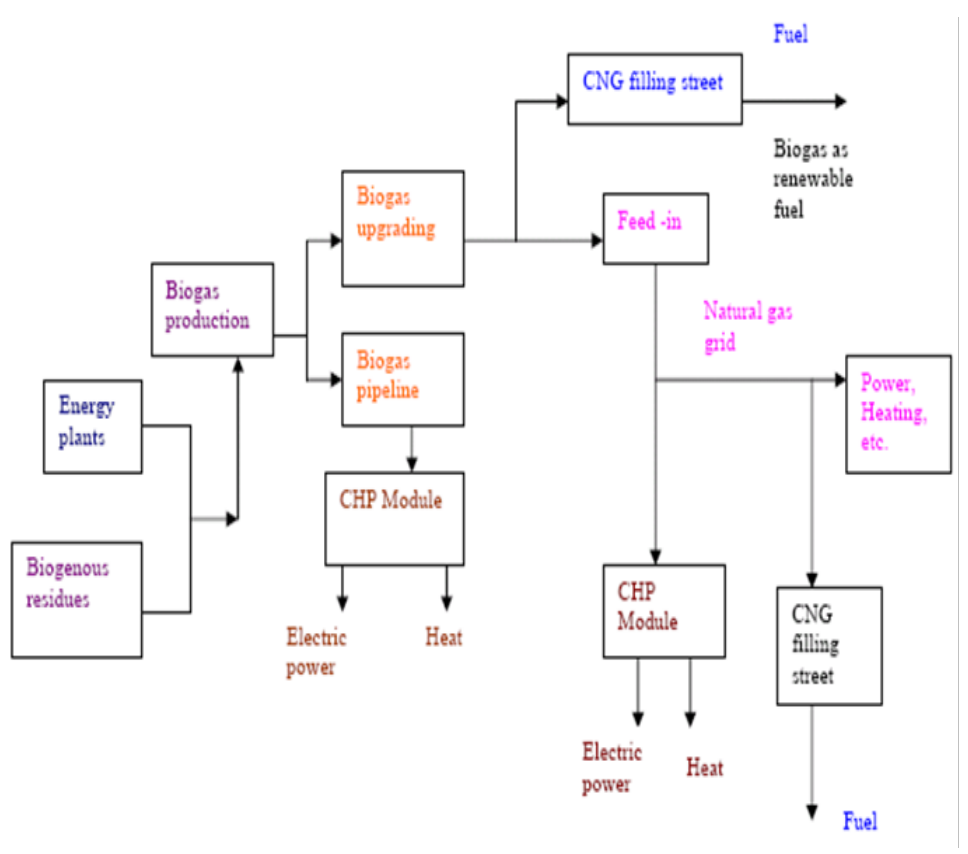

Figure 3 Overview of biogas utilisation pathways. ${ }^{17}$ 
A key concern is that treatment of sludge tends to concentrate heavy metals, poorly biodegradable trace organic compounds and potentially pathogenic organisms (viruses, bacteria and the like) present in wastewaters. These materials can pose a serious threat to the environment. When deposited in soils, heavy metals are passed through the food chain, first entering crops, and then animals that feed on the crops and eventually human beings, to whom they appear to be highly toxic. In addition they also leach from soils, getting into groundwater and further spreading contamination in an uncontrolled manner. European and American markets aiming to transform various organic wastes (animal farm wastes, industrial and municipal wastes) into two main by-products:

i. A solution of humic substances (a liquid oxidate).

ii. A solid residue.

\section{Ecological advantages of biogas technology}

An easier situation can be found when looking at the ecological effects of different biogas utilisation pathways. The key assumptions for the comparison of different biogas utilisation processes are:

A. Biogas utilisation in heat demand controlled gas engine supplied out of the natural gas grid with $500 \mathrm{kWe}$ - electrical efficiency of $37.5 \%$, thermal efficiency of $42.5 \%$, and a methane loss of 0.01 .

B. Biogas utilisation in a local gas engine, installed at the biogas plant with $500 \mathrm{kWe}$ - electrical efficiency of $37.5 \%$, thermal efficiency of $42.5 \%$, and a methane loss of 0.5 .

C. Biogas production based on maize silage using a biogas plant with covered storage tank - methane losses were $1 \%$ of the biogas produced.

D. Biogas upgrading with a power consumption $0.3 \mathrm{kWhe} / \mathrm{m}^{3}$ biogas - methane losses of 0.5 .

Figure 4 presents the results of the greenhouse gas (GHG) savings from the different biogas utilisation options, in comparison to the fossil fuel-based standard energy production processes. Biogas can be converted to energy in several ways. The predominant utilisation is combined heat and power (CHP) generation in a gas engine installed at the place of biogas production. There are mainly two reasons for this. First, biogas production is an almost continuous process; it is rather difficult or, in the short-term, even impossible, to control the operation of anaerobic digesters according to any given demand profile. Secondly, promotion of renewable energies is focused on electricity production. Because of that, biogas plant operators receive the predominant fraction of revenues from the guaranteed feed-in tariffs for electricity. Summarising the results of the eco-balances it becomes obvious that - not only by using fossil fuels but also by using renewable fuels like biogas - combined heat and power cogeneration is the optimal way for fighting climate change. From a technical point of view it can be concluded that biogas production, i.e., the conversion of renewable resources and biowaste to energy, can be seen as stateof-the-art technology. In an economic analysis, many factors have to be considered as outlined in Table 2. Due to the lack of knowledge and awareness, villagers cannot be expected to understand the benefits of solar stills, nutrient conservation, or health improvement. ${ }^{5} \mathrm{~A}$ poor rural peasant is very hesitant to enter a new venture. The negative attitude towards the use of stills water varies from place to place, but when it occurs, it is a major obstacle to the implementation of solar still technology. In designing the solar still, the following points were considered: the unit has to cost as little as possible and materials should be readily available in rural areas.

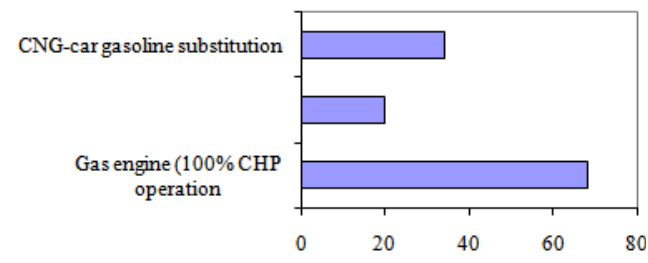

(\%)

Biogas upgrading

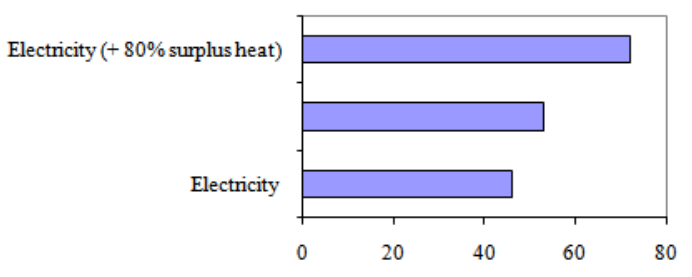

(\%)

Local gas engine

Figure 4 Greenhouse gas emissions savings for different biogas utilisation pathways in comparison to fossil energy production. ${ }^{17}$

Technology should be simple, within the reach of a common village man. The unit should be usable in situations of emergency, e.g., during floods and after cyclones, etc. Energy efficiency brings health, productivity, safety, comfort and savings to the homeowner, as well as local and global environmental benefits. The use of renewable energy resources could play an important role in this context, especially with regard to responsible and sustainable development. It represents an excellent opportunity to offer a higher standard of living to the local people, and will save local and regional resources. Implementation of renewable energy technologies offers a chance for economic improvement by creating a market for producing companies, maintenance and repair services. Production of bio-fuels such as ethanol from sugar cane, takes advantages of year-round cultivation potential in a tropical countries. Benefits extend from local, national and international levels. Local rural economies benefit through new economic opportunities and employment in the agricultural sector. Urban regions benefit through cleaner air and health improvements. The nation benefits through substituting domestic resources for costly imported gasoline. The world benefits from reduced $\mathrm{CO}_{2}$ emissions.

Bacteria form biogas during anaerobic fermentation of organic materials. The degradation is very complex process and requires certain environmental conditions as well as different bacteria population. The organic materials were biodegradable to produce biogas and the variation show a normal methanogene bacteria activity and good biological process shown in Figures $5 \& 6$. Gasification is based on the formation of a fuel gas (mostly $\mathrm{CO}$ and $\mathrm{H}_{2}$ ) by partially oxidising raw solid fuel at high temperatures in the presence of steam or air. 6,7 The technology can use wood chips, groundnut shells, sugarcane bagasse, and other similar fuels to generate capacities from $3 \mathrm{~kW}$ to $100 \mathrm{~kW} .^{8,9}$ Three types of gasifier designs have been developed to make use of the diversity of fuel inputs and to meet the requirements 
of the product gas output (degree of cleanliness, composition, heating value, etc.). The requirements of gas for various purposes, and a comparison between biogas; and various commercial fuels in terms of calorific value, and thermal efficiency are presented in Table 3.

Growth, modernisation and urbanisation in many states of Sudan have created both energy supply shortages and a growing source of free fuel: biogas. The use of biogas has been proven and is ready to be deployed in Sudan. The technology is available, it is economically feasible and it is reliable. An additional benefit of using these gases as a fuel source is minimization of the environmental impacts that result from gas venting or flaring. The burning of such gases will release air-borne pollutants, which can also enter groundwater sources and pollute farmlands. The optimum range in Table 4 is for ambient temperatures during hot seasons of Sudan tropical climates. The potential gas volumes produced from wastes vary depending on many factors (the amount of material fed, the type of material, the carbon/ nitrogen ratio and digestion time and temperature).

Table 2 Factors to be considered in economic analysis. ${ }^{17}$

\begin{tabular}{|c|c|c|c|}
\hline Economic factors & Social factors & Technical factors & Ecological/health factors \\
\hline Interest on loan & Employment created & $\begin{array}{l}\text { Construction, maintenance and } \\
\text { repairs of biogas plants }\end{array}$ & Improved health \\
\hline $\begin{array}{l}\text { Current/future cost of } \\
\text { alternative fuels }\end{array}$ & $\begin{array}{l}\text { Less time consumed for fetching } \\
\text { clean water }\end{array}$ & $\begin{array}{l}\text { Availability of materials and land } \\
\text { required }\end{array}$ & Environment pollution abatement \\
\hline $\begin{array}{l}\text { Current/future cost of } \\
\text { construction materials }\end{array}$ & $\begin{array}{l}\text { Improved facilities in villages; thus less } \\
\text { migration to cities }\end{array}$ & Suitability of local materials & $\begin{array}{l}\text { Improvement in yields of } \\
\text { agriculture products }\end{array}$ \\
\hline Saving of foreign currency & \multicolumn{3}{|l|}{ Less expense for buying alternative fuels } \\
\hline Current/future labour cost & \multicolumn{3}{|c|}{ More time for additional income earning activities } \\
\hline Inflation rate & & & \\
\hline
\end{tabular}

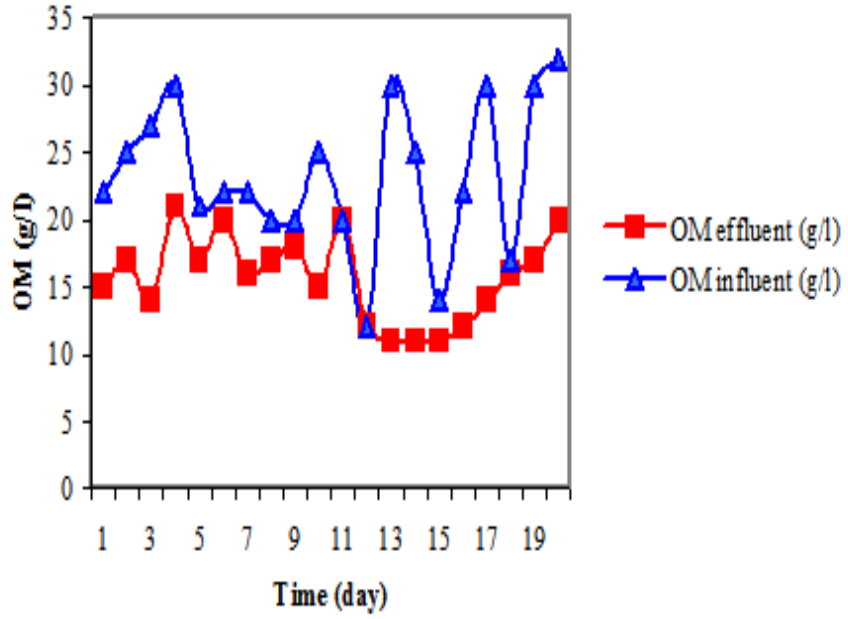

Figure 5 Organic matters before and after treatment in digester. ${ }^{24}$
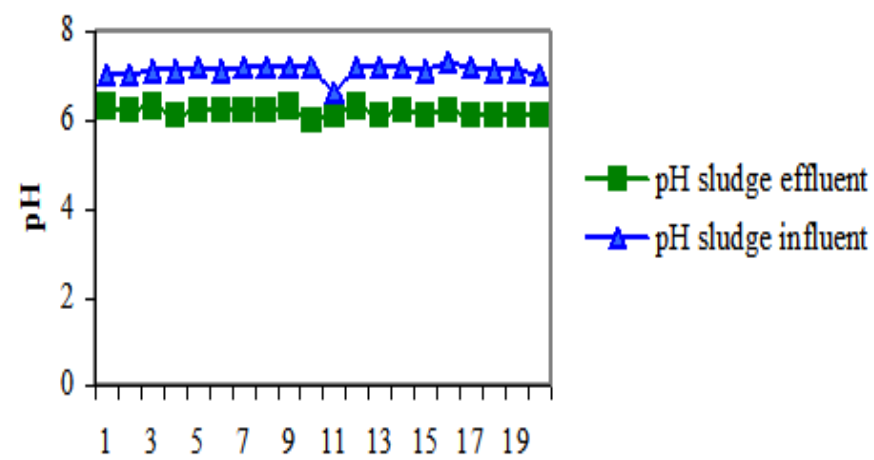

Time(day)

Figure $6 \mathrm{pH}$ sludge before and after treatment in the digester. ${ }^{24}$
Table 3 Comparison of various fuels. ${ }^{8}$

\begin{tabular}{llll}
\hline Fuel & $\begin{array}{l}\text { Calorific } \\
\text { value(kcal) }\end{array}$ & Burning mode & $\begin{array}{l}\text { Thermal } \\
\text { efficiency(\%) }\end{array}$ \\
\hline Electricity, kWh & 880 & Hot plate & 70 \\
Coal gas, kg & 4004 & Standard burner & 60 \\
Biogas, m3 & 5373 & Standard burner & 60 \\
Kerosene, I & 9122 & Pressure stove & 50 \\
Charcoal, kg & 6930 & Open stove & 28 \\
Soft coke, kg & 6292 & Open stove & 28 \\
Firewood, kg & 3821 & Open stove & 17 \\
Cow dung, kg & 2092 & Open stove & 11 \\
\hline
\end{tabular}

Table 4 Optimum conditions for biogas production. ${ }^{9}$

\begin{tabular}{ll}
\hline Parameter & Optimum value \\
\hline Temperature ${ }^{\circ} \mathrm{C}$ & $30-35$ \\
$\mathrm{pH}$ & $6.8-7.5$ \\
Carbon/Nitrogen ratio & $20-30$ \\
Solid content (\%) & 9 -Jul \\
Retention time (days) & $20-40$
\end{tabular}




\section{Biomass and sustainability}

There is an unmistakable link between energy and sustainable human development. Energy is not an end in itself, but an essential tool to facilitate social and economic activities. Thus, the lack of available energy services correlates closely with many challenges of sustainable development, such as poverty alleviation, the advancement of women, protection of the environment, and jobs creation. Emphasis on institution-building and enhanced policy dialogue is necessary to create the social, economic, and politically enabling conditions for a transition to a more sustainable future. On the other hand, biomass energy technologies are a promising option, with a potentially large impact for Sudan as with other developing countries, where the current levels of energy services are low. Biomass accounts for about one third of all energy in developing countries as a whole, and nearly $96 \%$ in some of least developed countries. ${ }^{10-12}$

\section{Environmental issues of biomass}

Climate change is a growing concern around the world, and stakeholders are aggressively seeking energy sources and technologies that can mitigate the impact of global warming. This global concern is manifest in the 1997 Kyoto Protocol, which imposes an imperative on developed nations to identify feasible options by the next Conference of the Parties to the Convention (COP) meeting later in 2001. Possible actions range from basic increases in energy efficiency and conservation, to sophisticated methods of carbon sequestration to capture the most common greenhouse gases (GHGs) emission $\left(\mathrm{CO}_{2}\right)$. On the other hand, renewable energies have always been identified as a prime source of clean energies that emit little or no net GHGs into the atmosphere. Forest ecosystems cause effects on the balance of carbon mainly by the assimilation of $\mathrm{CO}_{2}$ by the aboveground biomass of the forest vegetation. The annual emissions of greenhouse gases from fossil fuel combustion and land use change are approximately 33x 105 and $38 \times 105$ tonnes respectively. Vegetation and in particular forests, can be managed to sequester carbon. Management options have been identified to conserve and sequester up to $90 \mathrm{Pg} \mathrm{C}$ in the forest sector in the next century, through global afforestation. ${ }^{13,14}$ This option may become a necessity (as recommended at the Framework Convention on Climate Change meeting held in Kyoto), but a preventative approach could be taken, reducing total GHGs emissions by substituting biomass for fossil fuels in electricity production. Simply sequestering carbon in new forests is problematic because trees cease sequestering once they reach maturity, and as available land is used up the cost of further afforestation will grow.

Indeed the cost of reducing the build-up of GHGs in the atmosphere is already lower for fossil fuel substitution than for sequestration, since fast growing energy crops are more efficient at carbon removal, and because revenue is generated by the scale of electricity. Some biomass fuel cycles can also provide the additional benefits of enhanced carbon storage. The relative merits of sequestration versus fossil fuel substitution are still debated. The flow of carbon during the life cycle of the biomass should determine whether it is better left standing, used as fuel or used as long-lived timber products. Where there are existing forests in good condition there is general agreement that they should not be cut for fuel and replanted. This principle also concurs with the guidelines for nature protection, i.e., energy crops should never displace land uses of high ecological value. Where afforestation is undertaken, however, fossil fuel substitution, both by using wood fuel and using timber as a renewable raw material, should be more sustainable and less costly approach than sequestration could also be used to displace the harvest of more ecologically valuable forests. For efficient use of bioenergy resources, it is essential to take account of the intrinsic energy potential. Despite the availability of basic statistics, many differences have been observed between the previous assessments of bio energy potential..$^{15,16}$ These were probably due to different assumptions or incomplete estimations of the availability, accessibility and use of by products. The biomass sources have been used through:

\section{A. Anaerobic digestion of municipal wastes and sewage.}

\section{B. Direct combustion of forestry and wood processing residues.}

C. Direct combustion in the case of main dry crop residues.

D. Anaerobic digestion of moist residues of agricultural crops and animal wastes.

Wood is very important raw material used by a number of industries. Its excessive utilisation as a fuel results in soil erosion, degradation of the land, reduced agricultural productivity and potentially serious ecological damage. Hence, minimization of fuelwood demand at the national level and increase the efficiency of fuelwood use seems to be essential. Utilisation of more efficient stoves and improvement of insulation using locally available materials in buildings are also effective measures to increase efficiency. Biogas or commercial fuels may be thought of as possible substitutes for fuelwood. In rural areas of Sudan, liquefied petroleum gases (LPGs) are strong candidate to replace firewood. Indeed, increased, LPG utilisation over the last decade has been one of the main reasons has lead to the deceleration of the diffusion of biogas technology into rural areas.

\section{Energy from agricultural biomass}

The main advantages related to energy, agriculture and environment problems are foreseeable both regionally and globally and can be summarised as follows:

a) Reduction of dependence on import of energy and related products, and reduction of environmental impact of energy production (greenhouse effect, air pollution, waste degradation).

b) Substitution of food crops and reduction of food surpluses and of related economic burdens.

c) Utilisation of marginal lands and of set aside lands and reduction of related socio-economic and environmental problems (soil erosion, urbanisation, landscape deterioration, etc.).

d) Development of new know-how and production of technological innovation.

A study ${ }^{16}$ individuated on the basis of botanical, genetical, physiological, biochemical, agronomical and technological knowledge reported in literature some 150 species potentially exploitable divided as reported in Table 5. Turning to chemical engineering and the experience of the chemical process industry represents a wakening up but does not lead to an immediate solution to the problems. The traditional techniques are not very kind to biological products, which are controlled by difficulty and unique physico-chemical properties such as low mechanical, thermal and chemical stabilities. There is the question of selectivity. The fermentation broths resulting from microbial growth contain a bewildering mixture of many compounds closely related to the product of interests. By the standards of the process streams in chemical industry, fermenter is highly impure and extremely dilutes aqueous systems. The disadvantages of the 
fermentation media are as the following: mechanically fragile, temperature sensitive, rapidly deteriorating quality, harmful if escaping into the environment, corrosive (acids, chlorides, etc.), and troublesome (solids, theological, etc.), and expensive. Thus, pilot plants for scale-up work must be flexible. In general, they should contain suitably interconnected equipment for: fermentation, primary separation, cell disruption fractionalises and clarifications, purification by means of high-resolution techniques and concentration and dry. The effects of the chlorofluorocarbons (CFCs) molecule can last for over a century.

Table 5 Plant species potentially exploitable for production of agricultural biomass for energy or industrial utilisations. ${ }^{16}$

\begin{tabular}{ll}
\hline Groups of plants & Number of species \\
\hline $\begin{array}{l}\text { Plants cultivated for food purposes that can be } \\
\text { reconverted to new uses }\end{array}$ & 9 \\
$\begin{array}{l}\text { Plants cultivated in the past, but not in culture } \\
\text { any more }\end{array}$ & 46 \\
Plants cultivated in other world areas & 46 \\
Wild species, both indigenous and exotic & 47 \\
Total & 148 \\
Plant product & Number of species \\
Biomass & 8 \\
Sugars and polysaccharides & 38 \\
Cellulose & 17 \\
Hydrocarbons & 3 \\
Polymeric hydrocarbons & 5 \\
Gums and resins & 12 \\
Tannins and phenolic compounds & 3 \\
Waxes & 7 \\
Vegetable oils & 38 \\
Total & 131 \\
\hline
\end{tabular}

\section{Biogas digester desgins}

There are in practice two main types of biogas plant that have been developed; the fixed-dome digester, which is commonly called the Chinese digester, and the type with a floating gas holder known as Indian digester. The potential gas volumes produced from wastes vary depending on many factors, and can be expressed based in head count as shown in Table 6, or on a fixed weight as shown in Table 7. A list of the potential gas production from a number of materials is presented in Table 8. The requirements of gas for various purposes, and a comparison between biogas; and various commercial fuels in terms of calorific value, and thermal efficiency are presented successively in Table 9. The amount of biogas actually produced from a specific digester depends on the following factors: (1) Amount of material fed (2) Type of material (3) The carbon/nitrogen ratio and (4) Digestion time and temperature. Combined heat and power (CHP) installations are quite common in greenhouses, which grow high-energy, input crops (e.g., salad vegetables, pot plants, etc.).

Scientific assumptions for a short-term energy strategy suggest that the most economically efficient way to replace the thermal plants is to modernise existing power plants to increase their energy efficiency and to improve their environmental performance. However, utilisation of wind power and the conversion of gas-fired CHP plants to biomass would significantly reduce the dependence on imported fossil fuels. Although a lack of generating capacity is forecast in the long-term, utilisation of the existing renewable energy potential and the huge possibilities for increasing energy efficiency are sufficient to meet future energy demands in Sudan in the short-term. A total shift towards a sustainable energy system is a complex and long process, but is one that can be achieved within a period of about 20 years. Implementation will require initial investment, long-term national strategies and action plans. However, the changes will have a number of benefits including: a more stable energy supply than at present and major improvement in the environmental performance of the energy sector, and certain social benefits. A vision used a methodology and calculations based on computer modelling that utilised:

a. Data from existing governmental programmes.

b. Potential renewable energy sources and energy efficiency improvements.

c. Assumptions for future economy growth.

d. Information from studies and surveys on the recent situation in the energy sector.

In addition to realising the economic potential identified by the National Energy Savings Programme, a long-term effort leading to a 3\% reduction in specific electricity demand per year after 2020 is proposed. This will require: further improvements in building codes, and continued information on energy efficiency.

Table 6 Average daily gas production based on head count. ${ }^{25}$

\begin{tabular}{lll}
\hline Source of waste & $\begin{array}{l}\text { Waste production } \\
\left(\mathbf{k g ~ d}^{-1}\right)\end{array}$ & $\begin{array}{l}\text { Gas Production } \\
\left(\mathbf{m}^{3} \mathbf{~ d}^{-1}\right)\end{array}$ \\
\hline I cow & 10 & $0.25-0.40$ \\
I0 chicken & - & $0.02-0.04$ \\
I latrine user & I & $0.02-0.03$ \\
I sheep/goat & - & $0.02-0.04$
\end{tabular}

Table 7 Average gas production based on waste amount. ${ }^{27}$

\begin{tabular}{|c|c|c|}
\hline Source of waste & $\begin{array}{l}\text { Gas production } \\
\mathrm{m}^{3} / 103 \mathrm{~kg} \text { Animal }\end{array}$ & $\begin{array}{l}\text { Gas production } \\
\mathrm{m}^{3} / 103 \mathrm{~kg} \text { waste }\end{array}$ \\
\hline Dairy cattle & 2.53 & - \\
\hline Beef cattle & 2.47 & - \\
\hline Poultry & 6.92 & $65.5-115$ \\
\hline $\begin{array}{l}\text { Pretreated crop } \\
\text { waste }\end{array}$ & - & $30-40$ \\
\hline Water hyacinth & - & $40-50$ \\
\hline
\end{tabular}


Table 8 Ultimate gas yields for some different materials. ${ }^{27}$

\begin{tabular}{ll}
\hline Materials & Yield $\left(\mathrm{m}^{3} / \mathbf{k g}\right.$ day solids $)$ \\
\hline Manure & 0.34 \\
Cow & 0.48 \\
Poultry & 0.4 \\
Human & \\
Vegetable matter & \\
Straw & 0.17 \\
Grass & 0.43 \\
Leaves & 0.3 \\
Water hyacinth & 0.4 \\
\hline
\end{tabular}

Table 9 Biogas requirements for various purposes. ${ }^{27}$

\begin{tabular}{lll}
\hline Purpose & Specifications & $\begin{array}{l}\text { Gas required } \mathbf{( m}^{3} / \\
\text { day })\end{array}$ \\
\hline Cooking & per person & 0.425 \\
& stove $10 \mathrm{~cm}$ dia. & 0.47 \\
& 200 -candle power & 0.1 \\
Lighting & 40 -watt bulb & 0.13 \\
& 2-mantle & 0.14 \\
Gasoline engine & Per HP & 0.43 \\
Diesel engine & Per HP & 0.45 \\
Refrigerator & Per m3 & 1.2 \\
Incubator & Per m3 & 0.6 \\
Table fan (indirectly) & $30 \mathrm{~cm}$ diameter & 0.17 \\
Space heater & $30 \mathrm{~cm}$ diameter & 0.16 \\
\hline
\end{tabular}

\section{Discussions}

Financial hedges (such as futures and options) are contractual vehicles that convey rights and obligations to buy or sell a commodity at a specified price. Possible purchasing strategies using hedges are summarised in Table 10. These financial derivations are a method of reducing price risk with a relatively modest transaction price. Over the past 10 years the use of financial hedges has grown dramatically. Figure 7 illustrates various hypothetical reduction strategies and the resulting average fuel price. The basic concept is to utilise existing financial tools to guard against conditions that will negatively affect the operating budget. Basic hedges include:

A. Swap contract- a bilateral agreement with a party that agree to guarantee a 'fixed' price.

B. Future contract- a financial tool that limits upside price exposure.

C. Options contract- a financial tool that can limit upside and downside price exposure ('puts' are a hedge against falling prices, and 'calls' are a hedge against rising prices).

Politicians at the local and national level have evaluated sustainability as an important issue facing the communities. The future will have leaders who develop sustainable solid waste programmes that further improve the community to achieve the following: a) Reduce the generation of solid waste by establishing policies that encourage manufacturers to reduce packaging material volumes.

b) Promote the development of 'green' local secondary material manufacturing facilities through implementation of tax credits and incentives.

c) Thermally treat the remaining waste by either incineration or gasification and produce renewable 'green power' or 'green energy'.

d) Landfill the discarded/unusable material and Reuse/recycle/recover the pre-collection waste.

Table 10 Purchasing strategies using hedges. ${ }^{27}$

\begin{tabular}{ll}
\hline Strategy & Description \\
\hline Index & $\begin{array}{l}\text { Fuel is purchased month-by-month at a } \\
\text { first of the month index price }\end{array}$ \\
Forward physical & $\begin{array}{l}\text { Monthly fuel is purchased in advance for } \\
\text { an averaged fixed price }\end{array}$ \\
A fixed price for fuel is set, but 'put' \\
contracts are purchased to guarantee \\
that when future market prices for fuel \\
settle below the fixed cost, the monthly \\
price is adjusted downward towards the \\
tower index price
\end{tabular}

In compiling energy consumption data one can categorise usage according to a number of different schemes:

A. Traditional sector- industrial, transportation, etc.

B. End-use- space heating, process steam, etc.

C. Final demand- total energy consumption related to automobiles, to food, etc.

D. Energy source- oil, coal, etc.

E. Energy form at point of use- electric drive, low temperature heat, etc.

Table 11 lists the energy sources available. Table 12 presented some renewable applications.

Considerations when selecting power plant include the following:

a) Power level- whether continuous or discontinuous.

b) Cost- initial cost, total running cost including fuel, maintenance and capital amortised over life. 
c) Complexity of operation

d) Maintenance and availability of spares. e) Life.

f) Suitability for local manufacture.

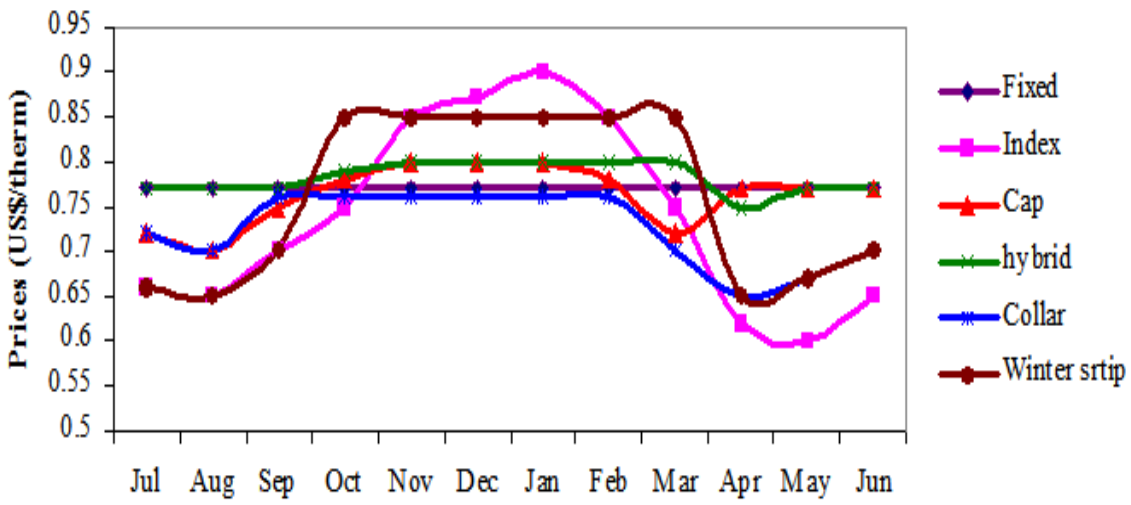

Figure 7 Purchasing strategies using hedges. ${ }^{28}$

Months

Table I I Sources of energy. ${ }^{17}$

\begin{tabular}{lll}
\hline Energy source & $\begin{array}{l}\text { Energy } \\
\text { carrier }\end{array}$ & Energy end-use \\
\hline Vegetation & Fuel-wood & Water heating \\
& & Building materials \\
Oil & Kerosene & Animal fodder preparation \\
& Dry cell & Ignition fires \\
Dry cells & Latteries & Lighting, Small appliances \\
& & Transport \\
Muscle power & Animal power & Land preparation for farming \\
& & Food preparation (threshing) \\
& & Transport \\
\hline Muscle power & Human power & Land preparation for farming \\
& & Food preparation (threshing) \\
\hline
\end{tabular}

Table 13 lists the most important of energy needs. Table 14 listed methods of energy conversion. A great amount of renewable energy potential, environmental interest, as well as economic consideration of fossil fuel consumption and high emphasis of sustainable development for the future will be needed. Explanations for the use of inefficient agricultural-environmental polices include: the high cost of information required to measure benefits on a site-specific basis, information asymmetries between government agencies and farm decision makers that result in high implementation costs, distribution effects and political considerations. ${ }^{18-20}$ Achieving the aim of agricenvironment schemes through:
A. Sustain the beauty and diversity of the landscape.
B. Improve and extend wildlife habitats.
C. Conserve archaeological sites and historic features.

D. Improve opportunities for countryside enjoyment.

E. Restore neglected land or features, and

F. Create new habitats and landscapes.

Table 12 Renewable applications. ${ }^{17}$

\begin{tabular}{ll}
\hline Systems & Applications \\
\hline Water supply & $\begin{array}{l}\text { Rain collection, purification, storage and } \\
\text { recycling }\end{array}$ \\
$\begin{array}{ll}\text { Wastes disposal } \\
\text { Cooking }\end{array}$ & $\begin{array}{l}\text { Anaerobic digestion }(\mathrm{CH} 4) \\
\text { Methane }\end{array}$ \\
Food & $\begin{array}{l}\text { Cultivate the I hectare plot and greenhouse } \\
\text { for four people }\end{array}$ \\
Electrical & Wind generator \\
demands & Solar collectors \\
Space heating & Solar collectors and excess wind energy \\
Water heating & Ultimately hardware \\
Control system
\end{tabular}

In some countries, a wide range of economic incentives and other measures are already helping to protect the environment. These include:

a. Taxes and user charges that reflect the costs of using the environment, e.g., pollution taxes and waste disposal charges.

b. Subsidies, credits and grants that encourage environmental protection.

c. Deposit-refund systems that prevent pollution on resource misuse and promote product reuse or recycling.

d. Financial enforcement incentives, e.g., fines for non-compliance with environmental regulations.

e. Tradable permits for activities that harm the environment.

District Heating (DH), also known as community heating can be a key factor to achieve energy savings, reduce $\mathrm{CO}_{2}$ emissions and at 
the same time provide consumers with a high quality heat supply at a competitive price. DH should generally only be considered for areas where the heat density is sufficiently high to make DH economical. In countries like Denmark DH may today be economical even to new developments with lower density areas due to the high level of taxation on oil and gas fuels combined with the efficient production of DH. ${ }^{21-30}$ To improve the opportunity for DH local councils can adapt the following plan:

A. Analyse the options for heat supply during local planning stage.

B. In areas where DH is the least cost solution it should be made part of the infrastructure just like for instance water and sewage connecting all existing and new buildings.

C. Where possible all public buildings should be connected to DH.

D. The government provides low interest loans or funding to minimise conversion costs for its citizens.

E. Use other powers, for instance national legislation to ensure the most economical development of the heat supply and enable an obligation to connect buildings to a DH scheme.

Table 13 Energy needs in rural areas. ${ }^{17}$

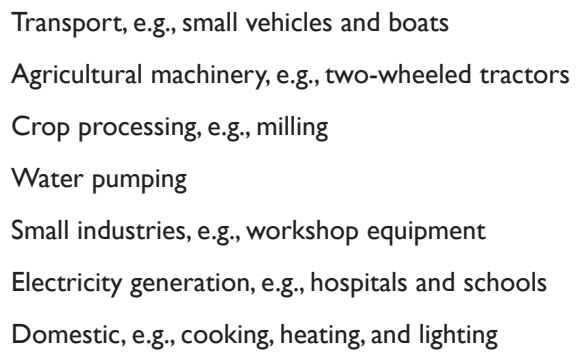

Table 14 Methods of energy conversion. ${ }^{17}$

\begin{tabular}{ll}
\hline Muscle power & Man, animals \\
\hline Internal combustion engines & \\
Reciprocating & $\begin{array}{l}\text { Petrol- spark ignition } \\
\text { Diesel- compression ignition }\end{array}$ \\
Rotating & Humphrey water piston \\
Heat engines & Gas turbines \\
Vapour (Rankine) & \\
Reciprocating & \\
Rotating & Steam engine \\
Gas Stirling (Reciprocating) & Steam engine \\
Gas Brayton (Rotating) & Steam turbine \\
Electron gas & Thermionic, thermoelectric \\
Electromagnetic radiation & Photo devices \\
Hydraulic engines & Wheels, screws, buckets, turbines \\
Wind engines (wind & Vertical axis, horizontal axis \\
machines) & Dynamo/alternator, motor \\
Electrical/mechanical & \\
\hline
\end{tabular}

Renewable energy policy model based biomass industry for rural electrification involving small and medium enterprises are very dependent on funding from non-banking agency is to make a feasibility study as a condition of the issuance of the power purchase agreement by state own electricity company. Based on the six elements studied then obtained the factors that influence energy policy based on renewable biomass from social forestry are: (1) the determination of the energy tariff, (2) competent human resources, (3) coordination between the related local government offices, (4) a system of incentives, (5) community participation, (6) funds and investment banking business, (7) microfinance, (8) the need for local governments to design spatial and territories. These factors should involve financial institutions, NGOs and Professional Association. Biomass is a renewable energy source that is important and will continue to be developed in the world. The development is now seen one of them in China that the development of biomass is very high, i.e., 3,511 MTCE (million tons of coal equivalent). Biomass highly distributed in China depends on the geography and climate in various provinces where development is still very necessary policies, and Feed -in Tariff incentives and subsidies for capital goods and research and development expenses also include tax incentives and pricing. Geographical distribution of biomass in China is unbalanced depending on the provinces of Sichuan, Yunnan and Tibet which is $33.3 \%$ of the total distribution in China. ${ }^{31-35}$

Renewable energy policy for the industrial private forest-based biomass has an input controlled or not controlled. Uncontrolled inputs include land use, land use rights, the exchange rate, the price of the product and the market demand. Controlled inputs include appropriate technology, human resources quality, supporting infrastructure, access to finance, supply chain systems and socialization. Input controlled and uncontrolled inputs along with the input environment (legislation, government regulation, public culture and agro-climate) produce the desired output in the form of job creation, the utilisation of forest products that are environmentally friendly, green growth, availability of renewable energy, and empowerment people and viable biomass energy rates. In addition to produce the desired output, the output is also obtained in the form of unwanted output: serviceability degradation, deforestation, high production costs and low public participation. These undesirable outputs into a feedback to management control and then the controlled input and renewable energy policy for the social forestry-based biomass industry will produce output that controllable. ${ }^{36}$ Utilisation of biomass, directly as firewood and charcoal for locals cooking purposes not included in the utilization of renewable energy. As for which is included in the utilisation of renewable energy is for electricity generation through biomass gasification process. Under these circumstances the research aims are: (1) identifying factors that influence development of renewable biomass energy policy, based on forest biomass managed by people (2) designing bio-pellet industry supply chain system with sustainable empowerment of community forests, and (3) developing renewable energy policy of biomass based industry, for rural electrification. The development of biomassbased renewable energy needs continuity of feedstock. It is strongly associated with land use and social conditions, related to community empowerment. Raw materials continuity can be supplied from forest harvest, both public forests and forest plantations. In this context, the development is directed to areas that have potency for widespread cultivated forest.

\section{Recommendations}

The introduction of biogas technology on wide scale has 
implications for macro planning such as the allocation of government investment and effects on the balance of payments. Factors that determine the rate of acceptance of biogas plants, such as credit facilities and technical backup services, are likely to have to be planned as part of general macro-policy, as do the allocation of research and development funds.

i. In some rural communities, cultural beliefs regarding handling animal dung are prevalent and will influence the acceptability of biogas technology.

ii. Co-ordination of production and use of biogas, fertiliser and pollution control can optimise the promotion and development of agricultural and animal husbandry in rural areas.

iii. Determine the energy rate bio-pellet eligible to stimulate biomass-based energy industry that is sustainable with fixed price provisions to ensure business certainty approved banks and financial institutions. It advised the Minister of Energy and Mineral Resources Regulation and mandated to state own electricity company.

iv. Facilitating access to financial institutions / banks in financing biomass-based energy industry by involving Non-Bank Financial Institutions such as Venture Capital scheme. Banking and Financial Institutions are expected to fund the Green Energy with incentives; i.e., lending rate is $2 \%$ below the central bank rate. Establish the rules of green banking in Banking and Financial Institutions sectors, this incentive for developers of renewable energy with a more attractive landing rate and below market rate so business people can obtain reliable funding sources for renewable energy projects.

v. Local Government should issue a Spatial Planning and Regional Governance and People's obvious that Employers have a legal framework in the area of Forest Plantation use, in addition to the Ministry of Forestry should be able to issue permits use of social forestry with a short-time and in the candy should be included at least 20\% social forestry for gardens Energy. Local government should provide education about social forestry for energy.

vi. This study can be continued for any type of renewable energy technology based on the amount of power, the power plant site and the technology used.

\section{Conclusion}

a. Biogas technology can not only provide fuel, but is also important for comprehensive utilisation of biomass forestry, animal husbandry, fishery, evoluting the agricultural economy, protecting the environment, realising agricultural recycling, as well as improving the sanitary conditions, in rural areas.

b. The biomass energy, one of the important options, which might gradually replace the oil in facing the increased demand for oil and may be an advanced period in this century. Any county can depend on the biomass energy to satisfy part of local consumption.

c. Development of biogas technology is a vital component of alternative rural energy programme, whose potential is yet to be exploited. A concerted effect is required by all if this is to be realised. The technology will find ready use in domestic, farming, and small-scale industrial applications. d. Support biomass research and exchange experiences with countries that are advanced in this field. In the meantime, the biomass energy can help to save exhausting the oil wealth.

e. The diminishing agricultural land may hamper biogas energy development but appropriate technological and resource management techniques will offset the effects.

\section{Acknowledgments}

None.

\section{Conflicts of interest}

Author declares that there is no conflict of interest.

\section{References}

1. Robinson G. Changes in construction waste management. Waste Management World. 2007. p. 43-49.

2. Sims RH. Not too late: IPCC identifies renewable energy as a key measure to limit climate change. Renewable Energy World. 2007;10(4):31-39.

3. Omer AM, Fallada Y. Biogas energy technology in Sudan. Renewable Energy. 2003;28(3):499-507.

4. Omer AM. Review: Organic waste treatment for power production and energy supply. Cells and Animal Biology. 2007;1(2):34-47.

5. Omer AM. Renewable energy resources for electricity generation in sudan. Renewable and Sustainable Energy Reviews. 2007;11(7):1481-1497.

6. Bacaoui A, Yaacoubi A, Dahbi C, et al. Activated carbon production from Moroccan olive wastes-influence of some factors. Environmental Technology. 1998;19(2):1203-1212.

7. Rossi S, Arnone S, Lai A, et al. ENEA's activities for developing new crops for energy and industry. In: Grassi G, Gosse G, editors. Biomass for Energy and Industry. USA; 1990. p. 107-113.

8. Omer AM. Renewable energy potential and future prospects in Sudan. Agriculture Development in Arab World. 1996;3:4-13.

9. FAO. State of the world's forest, Italy; 2009.

10. Haripriye G. Estimation of biomass in India forests. Biomass and Bioenergy. 2000;19(4):245-58.

11. Hall O, Scrase J. Will biomass be the environmentally friendly fuel of the future? Biomass and Bioenergy. 1998;15(4-5):357-367.

12. Omer AM. Biomass energy potential and future prospect in Sudan. Renewable \& Sustainable Energy Review. 2005;9(1):1-27.

13. Singh J, Sai Gu. Biomass conversion to energy in India: a critique. Renewable and Sustainable Energy Review. 2010;14(5):1367-1378.

14. Duku, Sai Gu, Essel BH. Comprehensive review of biomass resources and biofuels potential in Ghana. Renewable and Sustainable Energy Review. 2009;15(1):404-415.

15. Cheng, Timilsina, Jay J, et al. Advanced biofuel technologies: status and barriers. World Bank Report, WPS5411. 2010.

16. Bessou, Fabien F, Benoît G, et al. Biofuels, greenhouse gases and climate change. Agronomy for Sustainable Development. 2011;31:1-29.

17. Omer AM. Green energies and environment. Renewable and Sustainable Energy Reviews. 2008;12(7):1789-1821.

18. Pernille M. Feature: Danish lessons on district heating. Energy Resource Sustainable Management and Environmental. 2004. p. 16-17.

19. Erlich P. Forward facing up to climate change. In: Wyman, editor. Global Climate Change and Life on Earth. UK: Chapman and Hall; 1991. 
20. D'Apote SL. IEA biomass energy analysis and projections. In: Proceedings of Biomass Energy Conference: Data, analysis and Trends. Paris: OECD; 1998. p. 23-24,

21. International Energy Agency (IEA). Indicators for industrial Energy Efficiency and $\mathrm{CO}_{2}$ Emissions: A Technology Perspective. International Energy Agency. 2007.

22. Herath G. The Green Revolution in Asia: productivity, employment and the role of policies. Oxford Agrarian Studies. 1985;14(1):52-71.

23. Brain G, Mark S. Garbage in, energy out: landfill gas opportunities for CHP projects. Cogeneration and On-Site Power. 2007;8(5):37-45.

24. Abdeen MO. Development of integrated bioenergy for improvement of quality of life of poor people in developing countries. In: Flip LM, Oscar WB, editors. Energy in Europe: Economics, Policy and Strategy- IB. New York: NOVA Science Publishers; 2008. p. 341-373.

25. Omer AM. Environmental and socio-economic aspect of possible development in renewable energy use. Proceedings of the 4th ed, International Symposium on Environment. Athens, Greece; 2009. p. 21-24.

26. Omer A. Energy consumption, environment and sustainable development, In: Proceedings of the International Conference on Sustainable Energy and Environmental Protection (SEEP 2009). 3rd ed. Dublin: Republic of Ireland. 2009. p. 12-15.

27. Omer AM. Energy use and environmental: impacts: a general review. Journal of Renewable and Sustainable Energy. 2009;1(1):1-29.
28. Omer AM. Energy use, environment and sustainable development. In: Randi TM, editor. Environmental Cost Management. New York: NOVA Science Publishers; 2009. p. 129-166.

29. UNEP. Handbook for the International Treaties for the Protection of the Ozone Layer. United Nations Environment Programme. Nairobi, Kenya; 2003.

30. World Bank. World Development Report 2004: Making Services Work for Poor People. World Bank, Washington, DC. 2004.

31. Yongabi KA, Harris PL, Lewis DM. Poultry faeces management with a simple low cost plastic digester. African Journal of Biotechnology. 2009;8(8):1560-1566.

32. Cihan G, Dursun B, Bora A, et al. Importance of biomass energy as alternative to other sources in Turkey. Energy Policy. 2009;37(2):424-431.

33. Bhutto A, Bazmi A, Zahedi G. Greener energy: issues and challenges for Pakistan -Biomass energy prospective. Renewable and Sustainable Energy Reviews. 2011;15(6):3207-3219.

34. Omer AM. Applications of biogas: state of the art and future prospective. Blue Biotechnology Journal. 2012;1(2):335-383.

35. Kothari DP, Singal KC, Rakesh, et al. Renewable energy sources and emerging technologies. 2nd ed. India: Private Ltd, 2011.

36. Andrea S, Fernando R. Identifying, developing, and moving sustainable communities through renewable energy. World Journal of Science, Technology and Sustainable Development. 2012;9(4):273-281. 